\title{
Aquatic herbaceous plants of the Amazon floodplains: state of the art and research needed
}

Herbáceas aquáticas das áreas alagáveis amazônicas: estado da arte e estudos necessários

Maria Teresa Fernandez Piedade², Wolfgang Junk², Sammya Agra D’Ângelo ${ }^{1}$,

Florian Wittmann ${ }^{3}$, Jochen Schöngart ${ }^{3}$, Keillah Mara do Nascimento Barbosa ${ }^{1}$ and Aline Lopes ${ }^{1}$

${ }^{1}$ Monitoramento de áreas Úmidas Amazônicas, Grupo MAUA, Instituto Nacional de Pesquisas da Amazônia - INPA/CPBA, Projeto INPA/Max-Planck, CP 478, CEP 69011-970, Manaus, AM, Brazil

e-mail: maitepp@inpa.gov.br, sammya@inpa.gov.br, kmarantha@hotmail.com, alopesmga@gmail.com

${ }^{2}$ Grupo MAUA, Universidade do Estado do Amazonas - UEA e-mail:wjj@evolbio.mpg.de

${ }^{3}$ Department of Biogeochemistry, Max Planck Institute for Chemistry, Joh. J. Becher Weg 27, 55128 Mainz, Germany, Grupo MAUA, Projeto INPA/Max-Planck e-mail: F-Wittmann@web.de, jschoen@gwdg.de

\begin{abstract}
The Amazonian wetlands cover a vast area subject to a monomodal flood pulse with an annual amplitude averaging $10 \mathrm{~m}$, which defines an aquatic phase and a terrestrial phase of great biological importance. According to the geological origin and the catchment areas, the physical and chemical properties of the wetland will vary, being defined two major groups, the várzeas and the igapós. Although aquatic herbaceous plants do occur in the two types, higher species richness and densities are typical of the varzeas where aquatic herbaceous species, particularly $\mathrm{C}_{4}$ plants may exhibit high biomass values and net primary production - NPP about three times these of the floodplain forest. The aquatic herbaceous plants are very important in the carbon and nutrient budgets of the várzea, since through their decomposition they promote the enrichment of the aquatic system and associated floodplains, both during the aquatic and terrestrial phases of the hydrologic cycle. The major threats to herbaceous aquatic plants are related to the modification and contamination of the habitats owing to their use in economic activities as cattle and buffalo ranching and agriculture. Degradation improves the susceptibility of these systems to fire especially during the terrestrial phase, resulting in economic losses and further degradation of floodplains. Recently oil spills linked to the petroliferous activities in the region are of major concern demanding further and urgent evaluation.
\end{abstract}

Keywords: Amazon River, aquatic grasses, primary production.

Resumo: As áreas alagáveis amazônicas cobrem uma vasta extensão de terrenos submetidos a um pulso de inundaçâo monomodal de amplitude média anual de $10 \mathrm{~m}$, definindo uma fase aquática e uma fase terrestre de grande importância biológica. Conforme a origem geológica e as áreas de captação, a físico-química das áreas alagáveis irá variar, sendo definidos dois grandes grupos, as várzeas e os igapós. Apesar das plantas herbáceas aquáticas ocorrerem nessas duas tipologias, a maior riqueza de espécies e densidades são típicas da várzea, onde espécies aquáticas herbáceas, especialmente de plantas $\mathrm{C}_{4}$ podem apresentar valores de biomassa e produção primária líquida - PPL cerca de três vezes os da floresta de várzea. As plantas herbáceas aquáticas são muito importantes no balanço de carbono e nutrientes da várzea, uma vez que através da sua decomposição elas promovem o enriquecimento do sistema aquático e das áreas alagáveis associadas, tanto durante a fase aquática quanto terrestre do ciclo hidrológico. As principais ameaças para plantas herbáceas aquáticas estão relacionadas com a alteração e contaminação do habitat, devido à sua utilização em atividades econômicas como a pecuária de gado e búfalo e agricultura. A degradaçáo aumenta a suscetibilidade destes sistemas ao fogo, especialmente durante a fase terrestre, resultando em perdas econômicas e degradação adicional das áreas alagáveis. Recentemente derrames de óleo decorrentes das atividades petrolíferas na região são motivo de grande preocupação, exigindo urgentemente avaliação adicional.

Palavras-chave: Rio Amazonas, gramíneas aquáticas, produção primária. 


\section{Introduction}

A major challenge for botanists and ecologists is represented by the aquatic vegetation. This group of plants, defined by their affinity and or tolerance to water, is particularly interesting for ecological and ecotoxicological studies because their representatives are able to colonize environments with many different physical and chemical characteristics. Furthermore, by having short life cycles and high reproductive rates, aquatic plants are representative of current environmental conditions, unlike trees that respond to environmental changes more slowly (Junk and Piedade, 1997).

There are different definitions for aquatic plants and in the present study we adopt the definition of Sculthorpe (1985). Aquatic herbaceous plants are a group with a huge range of taxonomic levels within the plant kingdom a great number of species, habitats and habits. Thus, studying this group of plants is not a trivial exercise anywhere in the world. When it proposes to conduct such studies in the Amazon region, with its huge amount of Rivers and extensive floodplains the challenge gets even greater. Weaver and Clements (1938) formulated the broader definition of aquatic plants as "plants that grow in water, in soil covered with water or soil usually saturated with water." Even using this broad definition, the differentiation of herbaceous plants in aquatic and terrestrial is difficult, because the large Amazonian wetlands range between aquatic and terrestrial phases and are colonized by aquatic, paludal and terrestrial herbaceous species. The situation is complicated by the great morphological, anatomical and physiological plasticity used by many species to respond to annual hydrological changes (Figure 1).

To analyze a group of plants as diverse the peculiarities of the environment on a larger scale should be take into account. The assumed uniformity of the vegetation in the Amazon region in fact hide variations detectable by means of analyses of latitudinal gradients, from the most central part of the basin towards its borders. In the Occidental border the Amazonian physiognomy leaves the Brazilian territory and meets the preAndean and Andean region. Two eroded shields constitute the North and South limits, the Guyana's and Brazilian's shields, respectively. Thus, an analysis of the hydrological situation and its relation to the geomorphologic variables is necessary to understand the occurrence and diversity of the herbaceous aquatic plants in the region.
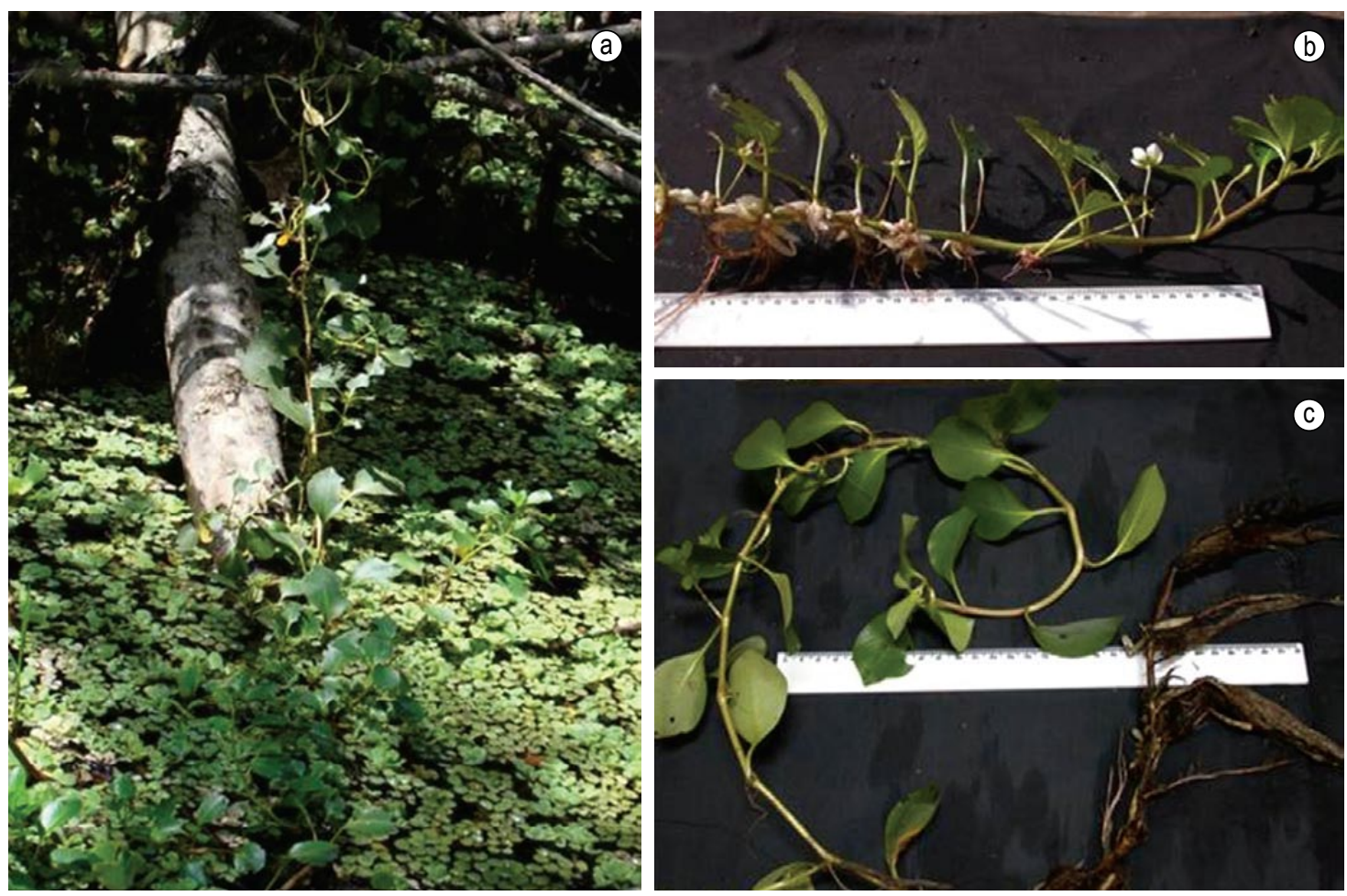

Figure 1. Morphological plasticity in Ludwigia helminthorrhiza (Onagraceae). a) plant's general aspect; b) roots with aerenchyma during the aquatic phase; and c) roots without aerenchyma during the terrestrial phase (Photos: S.A. D’Angelo). 


\section{The Amazon Basin its Drainage System and the Floodpulse}

The order of magnitude of the drainage system of the Amazon Basin is such that transport about $20 \%$ of all freshwater released in the world to the oceans (Goulding et al., 2003). The Amazon river responsible for delivering all this discharge to the sea forms along its margins extensive floodplanins which occur as well along its main tributaries, in a total area of ca. $400,000 \mathrm{~km}^{2}$ (Melack and Hess, 2010). Along the secondary rivers less evident although more numerous floodplains are formade. Since these smaller areas cover all the basin the surface of the floodplains they form is bigger than the major rivers. Near the sea large extensions of magroves are observed. A last kind of floodplains occur in flat areas with poor drenage. This kind of floodplains are mainly feeded by rain water and have a monomodal predictable floodpulse of long duration and small amplitude. Examples of this cathegory of floodplains are the Pantanal do Mato Grosso, Ilha do Bananal and the North savannas in Roraima State, Brazil (Junk, 2000). While for the transition from the Amazon region to the flooded areas of Central Brazil at the Pantanal do Mato Grosso several studies on the composition and ecology of herbaceous aquatic plants were developed or are still in couse, the transition to the Northern gradient (forest - savana) to herbaceos aquatic plants remains still to be done.

Floodplains in the Amazon will differ according to the water regime, nutrient status, vegetation cover, conexion with perennial water bodies and the potential for human utilization (Junk, 2000). A predictable monomodal pulse of long duration and high amplitude characterizes the floodplains associated to the big rivers whereas marginal areas of small rivers or streams (igarapés) will be flooded in na unpredictable mode of small amplitude and short duration responding to puntual events like localized rains. Coastal floodplains show a polimodal pattern of inundation pulse, predictable and of short duration and of amplitude from low to media owing to the tides (Junk, 1993).

In several floodplains at the transiction to the semi-arid regions both North and South of the umid forested Amazonia the terrestrial phase coincides with a heavy dry phase. After the period of hidric stress trees are subject to a heavy several dry stress during several months; this combination only allows the growth of semi-decidual vegetation of savannas (Junk, 1993). A belt of floodplain forests occur at permanent lakes and the marginal levees along the rivers. Inundated savannas in flat relief may show a abundant vegetation of aquatic macrophytes as observed at the Pantanal do Mato Grosso (Junk, 2000). Such phenomenum however has not yet being studied for the region North at the savannas of Roraima.

In the Central Amazon floodplains are associated with large rivers and maintain connections with these larger drainage systems, while regions of the savannas in Humaitá and Roraima are not associated with perennial water bodies. The connection with perennial water bodies is important to the composition of species and maintenance of biodiversity. Thus, floodplains connected with perennial large water bodies have great biodiversity and ability to recover quickly after catastrophic events through re-colonialization by propagating material from other areas, even after intense droughts. In areas without such connections with major water bodies the species whose populations can not be recomposed by land or by fragments of mother plants will endup being extinted. For example, in shallow lakes of flooded savannas of Roraima the number of fish species is low because they dry completely during heavy waterless periods and recolonization is only possible at times of extremely humid conditions, when the Lakes come in contact with permanent water bodies (Junk, 2000).

The floodplains connected to large rivers have high resilience against climate change, which reduces the rates of extinction. These areas could develop a large number of endemic species because paleoclimatic changes not affected seriously the system river-margins. On the other hand, the Pantanal do Mato Grosso, about 2,000 km South of Ecuador, has few endemic species, because the area has gone through several periods of extreme droughts with semi-arid conditions during the glacial periods (Ab'Saber, 1988). A similar pattern probably occurred in the Northern savannas, however, intensive field work is required to corroborate or not this trend.

The savannas flooded mainly by precipitation are fragile environments that receive a very low intake of nutrients by rainy water and small tributaries and suffer leaching during the flood period. Next to the canals of rivers these areas have many of the attributes of the associated rivers, however, as the distance from the channel grows, localized rainfall become more important. Finally, a high degree of independence of these water bodies and the rivers is established and, under such circumstances, they 
display nutrient cycles and species composition quite peculiar, with fauna and flora adapted to recycling of nutrients and to cope with the limited resources of these systems.

In the Amazon River and its large tributaries the hydrological cycle describes a regular monomodal pattern of inundation, with annual average amplitude of $10 \mathrm{~m}$ in the Central Amazon. As a result of this change in the water column, the floodplain vegetation is subjected every year to changes between an aquatic and a terrestrial phases with important ecological implications in both phases of the hydrological cycle (Junk et al., 1989). The lifecycles of species and the time available for growth depend on the habit of species and, in particular the duration of the terrestrial and aquatic phases of a given year. Therefore the floodpulse is the most important environmental pressure for the species of plants of these environments. Thus, throughout the year, pulses of growth and dormancy alternate, with changes in species of herbaceous vegetation according to the phase of the hydrological cycle considered (Junk and Piedade, 1997; Piedade and Junk, 2000).

\section{Types of Amazonian Floodplains}

About $6 \%$ of the Brazilian Amazon comprises the floodplains associated with large rivers, corresponding to the largest portion of floodplain forests of the world (Junk, 1993). According to the chemical and physicochemical properties of its waters floodplains are classified into two major groups, the várzeas, covering about $200,000 \mathrm{~km}^{2}$, or $4 \%$ of the region, and the igapós, whose approximate coverage area is $100,000 \mathrm{~km}^{2}$, or $2 \%$ of the region (Figure 2). The rivers associated to the várzeas have white waters, $\mathrm{pH}$ around neutrality, and carry a high load of sediments from the Andean and preAndean regions (Figure 2a), which are annually deposited in the margins promoting cyclical soil renewal, giving these environments high fertility (Sioli, 1951; Irion et al. 1983). The rivers associated to igapós have black or clear waters, originate in old and eroded areas of the Guyana's and Brazilian shields with predominant sandy soil (Figure $2 b$ ); its waters are acidic, with a $\mathrm{pH}$ ranging between 4 and 5 , poor in inorganic nutrients, and rich in organic material diluted, particularly humic and fulvic acids (Prance, 1978; Junk and Furch, 1991; Furch, 1984; Junk, 1984).

Although the floodplains are ecosystems with severe environmental characteristics which would limit the establishment of many plant species the interaction between frequency, magnitude and predictability of flood pulse allowed adaptation of plants to flood regime (Lytle and Poff, 2004). Floodplain forests in the Amazon with around 1000 tree species are the most diverse floodplain forests worldwide (Ferreira and Prance, 1998; Wittmann et al., 2002, 2006) and have a large number of endemic species (Wittmann et al., 2002). Some authors claim that the high resiliency of this type of vegetation would result in a low rate of extinction, contributing to the high plant diversity characteristic of the Amazon floodplains (Ab'Saber, 1988; Junk, 2000).

\section{The Communities of Herbaceous Plants of the Amazonian Floodplains and its Dynamics}

The survival in wetlands imposes on plants overcome the restrictions imposed by the periodic reduction of oxygen and the availability of light (Junk and Piedade, 1997). Hence, aquatic grasses
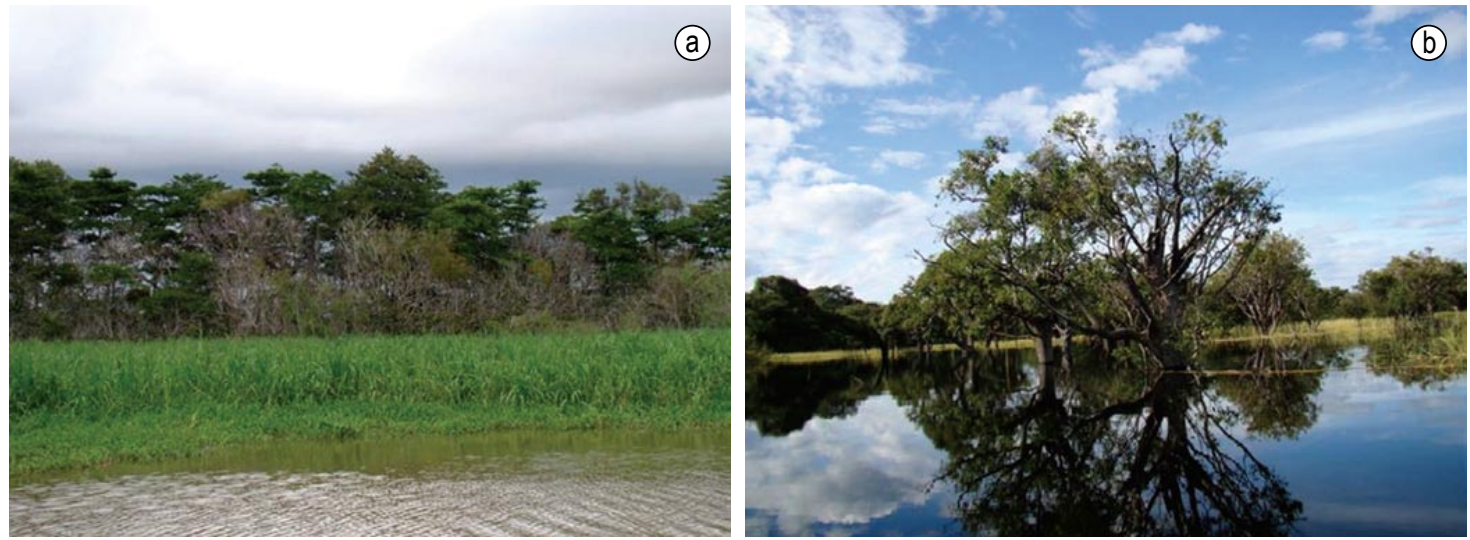

Figure 2. Typical floodplain landscapes: a) várzea at the Upper Rio Amazonas, Tabatinga - AM; and b) igapó at Rio Negro, Parque Estadual de Anavilhanas - AM (Photos: A. Lopes). 
may be considered the group of plants that better can cope with the periodic flooding, colonizing permanent lakes and areas where flooding can vary from a few weeks to almost the entire year (Junk et al., 1989). The ecological amplitude exhibit by aquatic plants is greatly facilitated by the fact that these plants have won the terrestrial environments, returning during the evolutionary process to aquatic environments (Sculthorpe, 1985) having developed progressive adaptations to aquatic life to allow different reactions to water level oscillations (Thomaz and Bini, 2003). These various adaptations which arose independently are reflected in the different habits found: submerged, floating, rooted with floating leaves and emergent. The distribution of aquatic grasses in the Amazon floodplains will depend on the duration of aquatic and terrestrial phases and the physical stability of the habitat, which is influenced by sedimentation, erosion and the sucessional processes, as well as the life cycle and age of plants and human impacts (Junk and Piedade, 1997). An important factor is the availability of light. For submerged plants light supply will depend on water transparency and floodpulse amplitude. In the black water of the Rio Negro and turbid water of the Solimóes/ Amazon, light penetrates only until depths from $50 \mathrm{~cm}$ to $2 \mathrm{~m}$ (Furch and Junk, 1997). During the aquatic phase owing to the large amplitude of the floodpulse submerged species rooted in the bottom easily die for lack of light. In shallow parts, the floodplain forest shades the surface of the water and inhibits the growth of grasses. Therefore, the diversity of aquatic plants in savannas swamped by a flood of low pulse amplitude and crystalline water is much greater than that in the Amazon. At the Pantanal, about 900 species of grasses occur, 248 of them considered aquatic (Pott, A. and Pott, VJ., 1996, 2000).

Also very important for the composition of herbaceous communities and for its biomass and productivity is the fertility status. Most of the varzea species are of fast growing and high productivity requiring high levels of nutrients as is the case of Paspalum repens P.J. Bergius, Paspalum fasciculatum Willd. and Echinochloa polystachya (H.B.K.) Hitchcock. These species proliferate along the Amazon River and its large fertile tributary where they highly contribute to the carbon balances and food chains of detritus (Junk and Piedade, 1993c). This contribution is the consequence of rapid growth, decomposition and nutrient cycling of these plants (Piedade and Junk, 2000).
Low concentrations of nutrients associated with acidity typical of areas of igapó are the main factors which explain the low quantity of aquatic grasses on these systems. Floating Species are rare, and during drought the beaches are not vegetated or only covered by rachitic vegetation (Piedade and Junk, 2000).

Analyzing the number of species of aquatic and terrestrial herbaceous plants, Amazonian várzeas appear to be richer than igapós (Figure 2). While in the várzea Junk and Piedade (1993a) identified 388 herbaceous species (Figure 3 ) in the igapós of Rio Negro less than $10 \%$ of this total was found (Piedade and Junk, 2000). However, this poverty may not be as marked but in fact being reflecting the scarcity of surveys of aquatic grasses in igapós, notably in these of black water. In an area of $53.6 \mathrm{~km}^{2}$ on the igapó of the River Jufarís (Amazonas State, Brazil), in forest environments $\left(6.25 \mathrm{~km}^{2}\right)$, beachs $\left(15.23 \mathrm{~km}^{2}\right)$, campinas $\left(25.17 \mathrm{~km}^{2}\right)$ and open waters $\left(7.0 \mathrm{~km}^{2}\right)$, found 55 species, belonging to 20 families (Figure 4) (Lopes et al., 2008). Most species found presented terrestrial habit being Cyperaceae ( $45 \%$ of species) and Poaceae (7.3\% of the species) the most common families. An opposite situation is observed in the várzea where the greatest amount was of Poaceae (32\% of species), followed by Cyperaceae (20\% of the species) (Junk and Piedade, 1993a). Considering only the data of this study, the percentage of grasses in black water increased from 10 to $14.2 \%$. Apparently the extreme conditions of igapós may induce a high degree of specialization, indicating the need for more surveys in these environments.

With the onset of the low water period in the várzea terrestrial annual grasses cover the lower portions of the floodplain. In these environments, the composition of species and their growth depend on the pattern of rainfall and water retention capacity of soils, varying greatly between different years. Higher portions not occupied by the floodplain forest are occupied by semi aquatic herbaceous plants well adapted to the dynamic of deposition of sediments (Junk and Piedade, 1997). Echinochloa polystachya, Paspalum fasciculatum and $P$. repens, are aquatic grasses which form extensive monoespecific stands with predominant asexual propagation, regrowing vigorously in the top layers of the soils, accelerating the processess of sediment retention. The free floating and emerging species dominate during the aquatic phase. If the inundation is very intense whole stands can be removed from the sediments. These plants are then taken by currents, serving as seedlings for colonization of newly created 

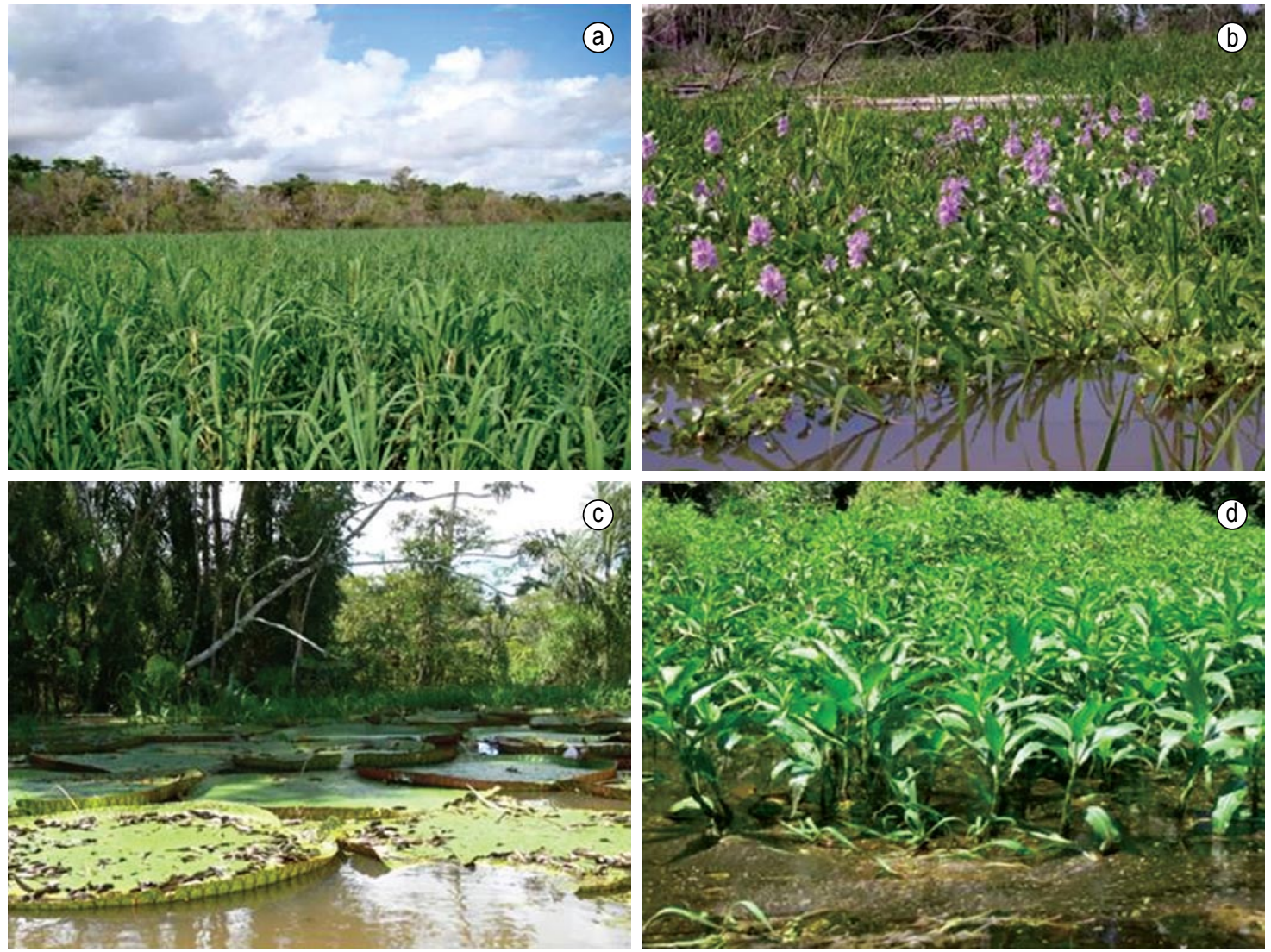

Figure 3. Floating aquatic herbaceous plants in the várzea floodplains of the Central Amazon: a) Echinochloa polystachya (Poaceae); b) Eichhornia crassipes (Pontederiaceae); c) Victoria amazonica (Nymphaeaceae); and d) Polygonum ferrugineum (Polygonaceae).

environments, as well as contribute to carbon stocks at the main channel of the fertile large rivers.

An important role of herbaceous vegetation is its ability to stabilize substrates via sediment retention, preventing erosion and promoting the first steps of the succession in várzea floodplains. The grasses E. polystachya and P. fasciculatum are the most important species in this retention due to their enormous amount of stems (Piedade et al., 1991; Worbes et al., 1992). The main factors of disturbance in these environments are currents and erosion that create a variety of different stages of sucession in floodplain areas (Junk and Piedade, 1997). Floodplain lakes isolated with smaller loads of deposition of sediments show a slow, however gradual process of succession. In those lakes the high clay content on the substrate has slow deposition and low sedimentary potential for aeration. On the other hand, in areas of sandy depositions or in the flat muddy regions of the main channel of the River processes are more dynamic and often reversible (Piedade and Junk, 2000).

Herbaceous plants can be divided into aquatic and terrestrial species and species that have adaptations to both phases. Among the 388 herbaceous species identified in the floodplain areas of Rio Amazonas 330 species $(85 \%)$ were classified as terrestrial plants, 34 (9\%) aquatic plants and the 22 remaining $(6 \%)$ as intermediary species (Junk and Piedade, 1993a). Most species (71\%) showed a preference for disturbed habitats in higher positions of the floodplain. Although the abundance of many of the species has been high, near Manaus only 12 species (3\%) may be considered as very abundant (Junk and Piedade, 1993b, c), and only 5 species (1\%) as dominant, forming monospecific stands, among them Echinochloa polystachya, Paspalum fasciculatum and $P$. repens. These $\mathrm{C} 4$ perennial grasses cover large areas with very high values of biomass (Junk and Piedade, 1993c). Due to the introduction of seeds of terrestrial invasive species along with seed for plantations, the number of species of herbaceous plants in higher parts of the floodplains tends to increase in the future. In most cases the adaptation of invasive species to the floodpulse restricts to the ability of seeds to survive the periodic flooding. Their survival during the terrestrial phase is facilitated by 

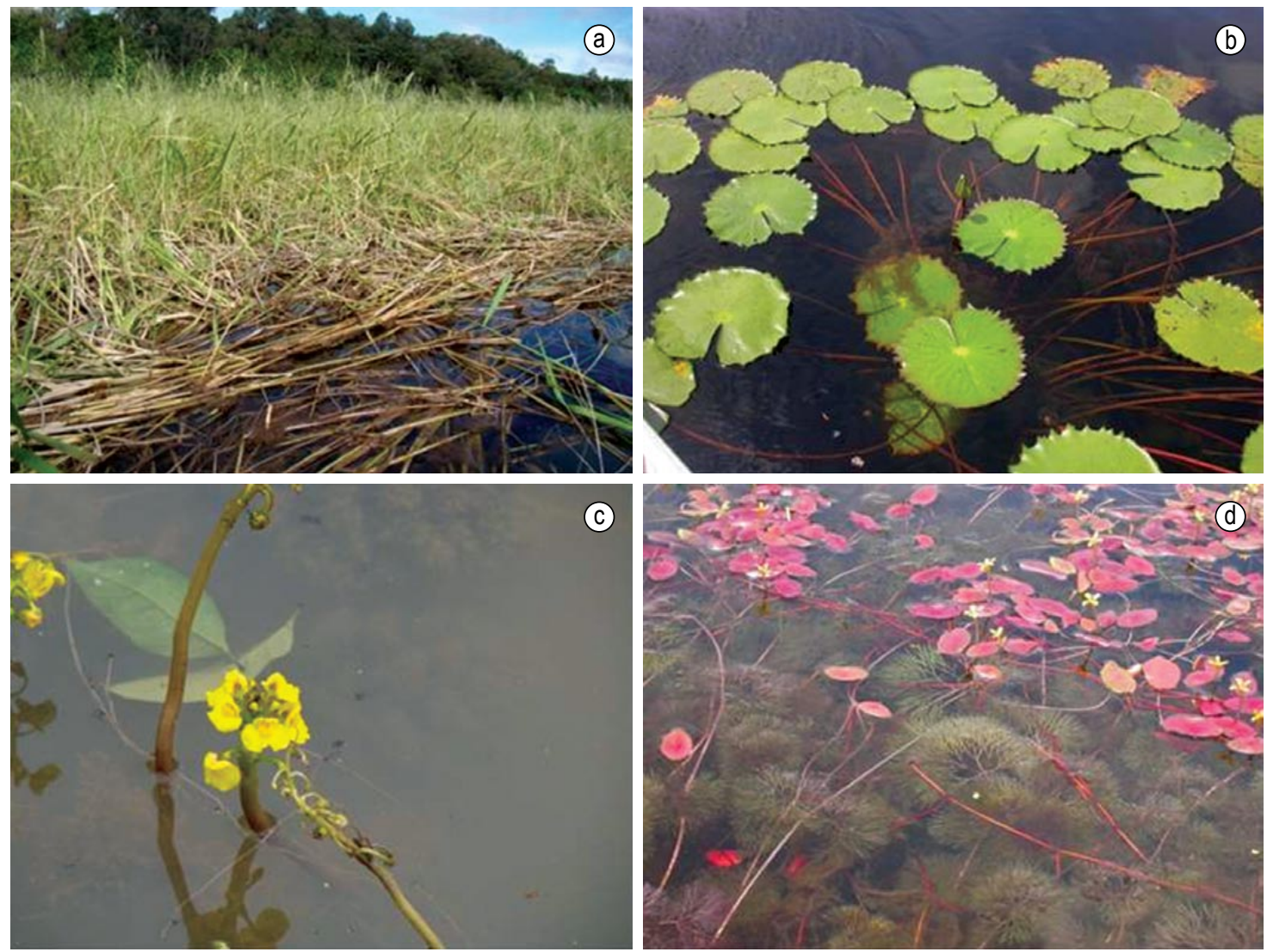

Figure 4. Common species found at the igapós of rio Negro: a) Oryza perennis (Poaceae); b) Nymphaea rudgeana (Nymphaeaceae); c) Utricularia foliosa (Lentibulareaceae); and d) Cabomba aquatica (Cabombaceae).

natural and human disturbance of habitats, which reduces competition with native species.

\section{Biomass and Primary Production of Amazonian Herbaceous Aquatic Plants}

Biomass and primary production depend on the species, life cycle and the time available for growth. Free floating plants as Salvinia auriculata Aubl., Ceratopteris pteridoides (Hook.) Hieron. and Pistia stratiotes $\mathrm{L}$. accumulate relatively low quantities of biomass per unit area, despite the high production values, due to its lateral expansion. Under optimal conditions for growth they duplicate its biomass in only six days. In a three-month period, the values of biomass of annual plant communities colonizing floodplain areas reached between $3.4( \pm 1.7)$ t.ha $^{-1}$ in Cyperaceae and even $8.7( \pm 5.3)$ t.ha $^{-1}$ in communities dominated by Aeschynomene sensitiva Sw. During the terrestrial phase mixed populations including Aeschynomene sensitiva, and during the aquatic phase Hymenachne amplexicaulis (Rudge) Nees and aquatic floating macrophytes, reached biomass 30 t.ha ${ }^{-1}$ in the period 9.5 months. Considering a monthly loss of biomass by decomposition and consumption between 10 and 25\%, net primary production (NPP) varies between 37-48 t.ha ${ }^{-1}$ (Junk and Piedade, 1993c). Mixed populations dominated by Paspalum repens and Oryza glumaepatula Steud. reached during a period of growth of 4 to 5 months, 14.5-17.5 t.ha ${ }^{-1}$. Values of biomass and NPP well above were registered for the perennial rooted species Paspalum fasciculatum and Echinochloa polystachya (Junk and Piedade, 1997).

$E$. polystachya grows in clay beds on the shores of the rivers and lakes and its life cycle relates to the aquatic phase, when the species maximizes productivity values. $P$. fasciculatum has its main growth period associated to the terrestrial phase. With the receding water the submerged stems are exposed and sprouts are rapidly formed on the nodes. Biomass of E. polystachya begins to dry when biomass of $P$. fasciculatum increases, maintaining biomass and NPP of the system at a high level throughout the year. $P$. fasciculatum reaches the maximum recorded biomass (53.6-57.6 t.ha ${ }^{-1}$, dry weight) in positions that are not flooded between 220 to 230 days per year (Junk and Piedade, 1993c). 
E. polystachya can achieve a value of biomass of 80 t.ha ${ }^{-1}$ in the period of one year (Piedade et al., 1991). The NPP of $P$. fasciculatum may reach $70 \mathrm{t}^{-\mathrm{ha}^{-1}}$ in a cycle of growth of around 8 months, while $E$. polystachya shows a value of 100 t.ha $^{-1}$ in one year (Table 1). These grasses can attain values of NPP up to three times the calculated values for várzea forest (Worbes, 1997) which shows the importance of these communities in the carbon cycle of the várzea floodplains (Piedade et al., 1994, 2001).

\section{Ecological Importance of Herbaceous Aquatic Vegetation as Habitat and in the Food Chains}

The retention of nutrients in biomass of aquatic grasses during periods of growth, as well as releasing during decomposition influences the electrolytic balance of lakes (Furch et al., 1983). The massive sequestration of nutrients during the aquatic phase and its subsequent return through decomposition during the terrestrial phase alter the balance of nutrients and increases the productivity in lakes and floodplains of Central Amazon.

The huge production of biomass and the large extension occupied set the aquatic herbaceous plants in a key position as habitats for aquatic and terrestrial fauna. The floating species E. crassipes developed a dense root system that can make up to 40 to $50 \%$ of the total plant's biomass. Aquatic grasses form adventitious roots in nodes of stems for the absorption of water and minerals. These roots and detritus associated provide shelter and food for aquatic organisms. The communities of aquatic plants are considered the most densely populated habitats among the water bodies of the várzea (Junk, 1973). Under conditions of adequate oxygen and low amounts of inorganic particles in suspension, a very high number of invertebrates $\left(780,000\right.$ ind. $\left.\mathrm{m}^{-2}\right)$ were found in association with stands of aquatic plants (Junk and
Robertson, 1997). When the stands are extremely dense concentration of oxygen decreases and toxic hydrogen sulphide may be produced reducing colonization by invertebrates.

Snails of the genus Pomacea often deposit their eggs in stems of grasses or petioles of $E$. crassipes (Merck, 1994), eating plants and detritus associated and shrimps use aquatic vegetation as shelter at least temporarily (Ordinez-Collart, 1988). The most important group using aquatic herbaceous plants as habitats among aquatic vertebrates are fish, particularly the young, which avoid predation finding shelter and food among the stems, roots and leaves. Fish can also use oxygen released into the water by the roots of some aquatic plants in periods of intense hypoxia (Jedicke et al., 1989), however, studies with stable isotopes of carbon performed by Forsberg et al. (1993) indicate that the plant material derived of macrophytes is relatively little consumed by fish.

A large number of terrestrial invertebrates colonize herbaceous plants associated with the terrestrial phase of the hydrological cycle. Grasshoppers are among the most important consumers. Paulinia acuminata (De Geer,1773), for example feed and lay eggs in Pistia stratiotes and Salvinia spp. (Vieira, 1989; Vieira and Adis, 1992) while Stenacris fissicauda fissicauda (Bruner, 1908) feed and lay eggs in Paspalum repens (Nunes, 1989).

The Manatee (Trichechus inunguis Natterer, 1883) and capybara (Hydrochoerus hydrochaeris L., 1766) are the most important mammals consuming large amounts of aquatic herbaceous plants. However, current populations of these animals have declined dramatically as result of intensive hunting. The same situation is observed in relation to large river turtle (Podocnemis spp.) that besides the intensive hunting have the eggs predated for animals and humans (Junk and Silva, 1997). Several

Table 1. Net Primary Production (NPP; dry weight) for the most important populations and communities of aquatic herbaceous plants in the Central Amazon várzea.

\begin{tabular}{lcc}
\hline \multicolumn{1}{c}{ População/comunidade } & $\begin{array}{c}\text { Maximum NPP } \\
\text { (t.ha }^{-1} \text { ) }\end{array}$ & $\begin{array}{c}\text { Time for production } \\
\text { (months) }\end{array}$ \\
\hline Monospecific stands of Echinochloa polystachya (Kunth) Hitchcock * & 100.0 & 12.0 \\
Monospecific stands of Paspalum fasciculatum Willd. ${ }^{* *}$ & 70.0 & 7.7 \\
Mixed populations dominated by Hymenachne amplexicaulis (Rudge) Nees ** & 48.0 & 9.5 \\
Monospecific stands of Paspalum repens P.J. Bergius ** & 33.0 & 4.0 \\
Monospecific stands of Oryza perennis Moench ** & 27.0 & 4.0 \\
Mixed populations dominated by Oryza perennis Moench ** & 17.5 & 5.0 \\
\hline
\end{tabular}

${ }^{*}$ Piedade et al. 1991; **Junk and Piedade, 1993c; ${ }^{* * *}$ Maximum period of growth of population or communities under natural conditions. 
species of birds feed on seeds of aquatic grasses in várzea floodplains.

\section{The Use of Aquatic Herbaceous Plants in Amazonia}

Aquatic plants are grown since ancient times in the history of mankind, especially in the Orient (Sculthorpe, 1985). Nevertheless, despite the great diversity of aquatic plants in the Amazon, the information on their use by indigenous peoples in the period prior to Columbus is scarce. This possibly is related to the rapid disintegration of social structures of the varzeas's indigenous peoples and their decimation after the arrival of European colonists (Piedade and Junk, 2000). Nowadays the use of herbaceous aquatic plants by human populations in the Amazon is very poor, practically restricted to feeding of livestock. Even common uses in other countries such as the production of paper and derivatives, civil construction and ornamentation of water bodies (Sculthorpe, 1985) are non-existent in the Brazilian Amazon. Some of the potential uses of herbaceous aquatic plants are summarized below.

\subsection{Soil fertilization}

The high biomass produced by herbaceous aquatic plants can be used for soil fertilization. Experiments testing the effectiveness of the application of aquatic plants in plantations have already been made in the Amazon region with promising results, especially in plantations of wing-beans, Psophocarpus tetragonolobus (L.) DC (Noda et al., 1978). In Echinochloa polystachya plantations in várzea the addition of chopped leaves of the same species in the soil led to an increase in biomass of $120 \%$ compared to treatments without covering of soil and nitrogen fertilization (Schlegel, 1998). As the species has water content exceeding $80 \%$, adding the plant material can reduce water shortages of plantations during the phase of drought.

\subsection{Animal breeding}

With the breeding of cattle and buffaloes in the Amazon, artificial pastures were also introduced. In the last decades these pastures are formed predominantly by the African grass Brachiaria humidicola (Rendle) Schweick., although, native aquatic grasses are used as well (Ohly and Hund, 1996). The selectivity by certain items is great among the animals. For example, the grass Paspalum fasciculatum is well-accepted by buffaloes, but rejected by cattle. During high water levels Echinochloa polystachya is offered to bovine animals confined in "marombas", floating corrals where livestock remains during floods. Buffaloes swim up the communities of aquatic plants for food; however, intensive foraging by buffaloes can reduce herbaceous species diversity. Analyzing the composition of species in a grazing várzea used by buffaloes over a period of 10 years a 50\% reduction in the diversity of species was observed (Conserva and Piedade, 1998), indicating risks to biodiversity if the carrying capacity of environment is exceeded. Rations for feeding fish of the species Brycon cephalus were made with Eichhornia crassipes (Saint-Paul et al. 1981) and Salvinia spp. (Pereira Filho et al. 1987) with good results.

\subsection{Traditional medicine and human consumption}

Despite the great richness of aquatic plants in the Amazon basin, only a few traditional human populations use some species for medicinal purposes. Macerated leaves of Montrichardia arborescens (L) Schott (Araceae) are used in plasters against inflammations, while the powder of roots of the same species is used as a diuretic. Several Euphorbiaceae from genus Phyllanthus occurs in the region, being the most well-known $P$. niruri $\mathrm{L}$., with recognized medicinal properties in dissolution of kidney stones (Garcia et al., 2004).

Some indigenous peoples use the ashes of Eichhornia crassipes to extract salt. Two species of wild rice native from Brazil, Oryza grandiglumis and O. glumaepatula, occurring in Central and Western Amazonia (Oliveira, 1992) have been consumed in the past by riverside human populations (Rubim, 1995). The production of seeds of these two species is estimated at only 1 t.ha ${ }^{-1} \cdot$ year $^{-1}$ (Soares et al., 1986). The seeds and rhizomes of Victoria amazonica (Poepp.) J.C. Sowerby (Nymphaeaceae) are referred to as alimentary items of floodplain populations. Neptunia oleracea Lour. and Ipomea aquatica Forssk., common species in Central Amazon várzea floodplains are regularly consumed in Asia (Sculthorpe, 1985).

\section{Impacts on Aquatic Herbaceous Plants From the Amazon Wetlands and its Implications}

The main problem affecting Amazonian aquatic plants refers to the destruction of their habitats. The removal of forests increasing the incidence of light can lead to an intense growth of some aquatic plants, especially grasses as Paspalum fasciculatum and 
Echinochloa polystachya. However, if the deforested area is too large loss of sediments to the river will be facilitated by turbulence and water currents. Under such circumstances the establishment of these species may be hindered and so the succession that leads to the recomposition of the original environment. Another important aspect that is increasing the risk to these plants is its susceptibility to fire. Because this vegetation did not develop adaptations to fire it can be easily removed, especially if intense droughts occur (Junk and Piedade, 1997).

An important factor demanding attention especially in the várzeas comes from the potential contamination of oil and its derivatives, regularly transported along the Amazon/Solimóes River on a journey of $650 \mathrm{~km}$ from the city of Coari to Manaus. The intensification of extraction and transport in the region of Urucu, where the oil is being extracted involve risks of accidents that should be considered (Lopes, 2007). With the purpose of evaluating the effects of a spillage on the growth of two key species, E. polystachya and Eichhornia crassipes, several experiments were conducted. The effect of the Urucu's oil in growth and vegetative propagation of E. polystachya, was evaluated since this process is essential for the species' maintenance in a given habitat; at a concentration of $0.46 \mathrm{~L} \cdot \mathrm{m}^{-2}$ of soil of oil regrowth decreased by $50 \%$. Growth also suffered $50 \%$ reduction even in a lower dosage of $0.12 \mathrm{~L} . \mathrm{m}^{-2}$ of soil (Lopes and Piedade, 2009); lethal dosage to eliminate $50 \%$ population $\left(\mathrm{DL}_{50}\right)$ was estimated at $0.47 \mathrm{~L} . \mathrm{m}^{-2}$ in only four days (Lopes et al., 2009).

In experiments of exposure to Urucu's oil using the floating aquatic species E. crassipes, Lopes et al. (2009) estimated in $1.24 \mathrm{~L}^{-\mathrm{m}^{-2}}$ the $\mathrm{LD}_{50}$ for the species in 91 days of exposure: cellular disorganization was observed when plants were maintained over a 90 days period at the concentration of $15.89 \mathrm{~L} . \mathrm{m}^{-2}$ of oil. As E. crassipes is of great importance housing fish communities in the extensive root system (Botero et al., 2003), massive mortality of this species or its contamination will increase the exposure of fish to the pollutant. As several other animals use E. polystachya and $E$. crassipes as refuge and food source, an oil spill in várzea floodplains will cause serious damage to the flora, and indirectly or directly can cause damage also to the fauna of these environments.

Intensive agriculture in Amazonian floodplains is introducing fertilizers and pesticides in these environments. The quantities of toxic compounds, including metals, accumulated by these practices is unknown, since the monitoring of their marketing and implementation is incipient. This is an important aspect that should be studied in the future and which, along with prospecting for gold represents a serious environmental issue and public health for these areas. As the agricultural and fishing activities constitute the basic diet for majority of the population of Amazonia, contamination of this kind can propagate and should be carefully analyzed by decision makers, politicians and the scientific community.

\section{Final Remarks}

Historically Amazonian floodplains especially the várzeas due to its high fertility have been focal areas of colonization, intensified over the last thirty years. The change of the traditional way of using these environments, originally linked to the subsistence fishing and small-scale agriculture, for the introduction of other practices such as extensive agriculture, timber extraction and rearing animals had strong influence on resident populations of herbaceous plants. During the last decades the cutting of forests and the removal of herbaceous aquatic vegetation to introduce exotic pastures brought several negative consequences such as loss of biodiversity, soil and its fertility, and also the loss of fertility of water bodies.

In the várzea floodplains the aquatic and terrestrial herbaceous plants occupy a large area, playing a key role in the ecosystem as habitat for aquatic and terrestrial fauna and food supply for some key species of animals. These plants also trap sediments and nutrients and protect the surface layers of soil against erosion; its removal to make way for massive plantations of species less adapted will reduce the fertility of the floodplain, requiring additional fertilization. Furthermore, during the terrestrial phase the susceptibility of secondary vegetation to fire increases, leading to an even greater degradation of the natural communities of plants and their associated fauna. Aquatic herbaceous plants, especially the grasses E. polystachya and P. fasciculatum begin the process of semi-terrestrial succession culminating in the establishment of woody species in the várzea. These herbs can be considered as "engineering species" as defined by Jones et al. (1994), owing to its ability to model the resources and structure of the environment where they settle. The removal of these species may compromise the processes of succession and the establishment of trees in early successional stages of the floodplain forests. 
With the clearing of the forest communities of herbaceous floodplain species proliferate, increasing the total primary production of the given period because these native communities are more productive than the forest itself. A major decline, however, will take place at the biomass stocks level, since they are much higher in flooded forests. At igapó areas that dynamic is poorly known, although it is assumed that in these nutritionally poor and acidic environments the composition of herbaceous aquatic plants differs, species richness is limited or the plants are scrubby. Due to its lower sediment load and nutrient content, the igapós are less dynamic compared to the várzea. Under such circumstances, herbaceous aquatic plants with short life cycles are unlikely to compete with woody plants of long life cycles. However, this issue needs further development, since recent studies show that the richness of herbaceous species in these environments may be greater than that reported so far by the lack of surveys, particularly critical in environments of black water. In this regard, studies on these systems in the Amazon are fundamental and should be strongly encouraged.

Finally, the oil extraction in the Amazon Basin, a relatively recent activity in development in várzea areas, may constitute a serious problem for the species of herbaceous plants of such systems. The massive mortality observed in previous studies with the species Eichhornia crassipes and Echinochloa polystachya may constitute a major problem for the várzea floodplain given the relevance of these species as shelter and food source for many aquatic and terrestrial organisms, spreading the contamination through the food chain for other levels of the biota. Besides, in the case of $E$. polystachya species with a very high primary production (Piedade et al., 1991), mass mortality in a short period of time imply an abrupt interruption of the incorporation of carbon together with the introduction of contaminated material in the system (Lopes and Piedade, 2009). This material distributed during the high water level thanks to the connectivity and flood pulse (Thomaz et al., 2004), can disperse contaminants to diverse locations in the river systems of the region. These aspects should be studied in greater depth, given the imminent expansion of oil and gas activities in wetlands of the region (ANP, 2010).

\section{Acknowledgements}

The authors acknowledge the funding of FAPEAM / CNPq through the PRONEX Project "Tipologias alagáveis" and the CNPq "Edital
Universal" (486093-2007). INPA has supported funding the PPI MAUA (1090-5); additional support has been provided by the Project INPA/ Max-Planck. Finally, field activities would not have been possible without the help and experience of Celso Rabelo Costa, Valdeney Araujo Azevedo, and the "boatmen" from the Coordination of Research in Aquatic Biology - CPBA/INPA.

\section{References}

AB'SABER, AN. 1988. O pantanal mato-grossense e a teoria dos refúgios. Revista Brasileira de Geografia, vol. 50, p. 9-57.

Agência Nacional do Petróleo, Gás Natural e Biocombustíveis - ANP. 2010. Produção Nacional de Petróleo e LGN (barris). Boletim Mensal de Produção, conforme o Decreto n. ${ }^{\circ}$ 2.705/98.

BOTERO, JIS., FARIAS, ML., DE PIEDADE, MTF. and GARCEZ, DS. 2003. Ictiofauna associada às macrófitas aquáticas Eichhornia azurea (SW.) Knuth. e Eichhornia crassipes (Mart.) Solms. no lago Camaleão, Amazônia Central, Brasil. Acta Scientiarum, vol. 2, no. 25, p. 369-375.

BRUNER, L. 1908. Acrididae. Biologia Centrali Americana, vol. 2, p. 249-342.

CONSERVA, AS. and PIEDADE, MTF. 1998. Influence of flood-pulse and land-use on the composition of herbaceous species on a floodplain in Central Amazonia. Verhandlungen des Internationalen Verein Limnologie, no. 26, p. 994-99.

FERREIRA, LV. and PRANCE, GT. 1998. Structure and species richness of low-diversity floodplain forest on the Rio Tapajos, Eastern Amazonia, Brazil. Biodiversity and Conservation, vol. 7, p. 585-596.

FORSBERG, BR., ARAUJO-LIMA, CRAM., MARTINELLI, LA., VICTORIA, RL., and BONASSI, JA. 1993. Autotrophic carbon sources for fish of the Central Amazon. Ecology, no. 74, p. 643-65.

FURCH, K. 1984. Water chemistry of the Amazon Basin: the distribution of chemical elements among freshwaters. In SIOLI, H. (Ed.). The Amazon Limnology and landscape ecology of a mighty tropical river and its basin. Dordrecht: Junk. p. 167-169.

FURCH, K. and JUNK, WJ., 1997. Physicochemical conditions in the floodplains. In: JUNK, W.J. (Ed.). The Central Amazon floodplain: Ecological Studies. Berlin: Springer. p. 69-108.

FURCH, K., JUNK, WJ., DIETERICH, J. and KOCHERT, N, 1983. Seasonal variation in the major cation $(\mathrm{Na}, \mathrm{K}, \mathrm{Mg}$ and $\mathrm{Ca}$ ) content of the water of Lago Camaleão, an Amazon floodplain lake near Manaus, Brazil. Amazoniana, vol. 8, no. 1, p. 75-90. 
GARCIA, GM., ZANETTI, GD., ZAGO, AM., BITTENCOURT, CF. and HEINZMANN, BM. 2004. Estudo Morfo-Anatômico de Phyllanthus niruri L. e Phyllanthus tenellus Roxb. Acta Farmaceutica Bonaerense, vol. 23, no. 1, p. 67-70.

GOULDING, M., BARTHEM, R. and FERREIRA, E. 2003. The Smithsonian Atlas of the Amazon. Washington DC: Smithsonian Institution Press.

IRION, G., ADIS, J., JUNK, WJ. and WUNDERLICH, F. 1983. Sedimentological studies of the "Ilha de Marchantaria" in the Solimóes/Amazon River near Manaus. Amazoniana, vol. 3, p. 1-18.

JEDICKE, A., FURCH, B., SAINT-PAUL, U. and SCHLÜTER, U. 1989. Increase in the oxygen concentration in Amazon waters resulting from the root exudation of two notorious water plants, Eichhornia crassipes (Pontederiaceae) and Pistia stratiotes (Araceae). Amazoniana, vol. 11, no. 1, p. 53-69.

JONES, CG., LAWTON, JH. and SHACHAK, M. 1994. Organisms as ecosystem engineers. Oikos, vol. 69, p. 373-386.

JUNK, WJ. 1973. Investigation on the ecology and productionbiology of the floating-meadows. PaspaloEchinochloetum of the middle Amazon. II. The aquatic fauna in the root zone of floating vegetation. Amazoniana, vol. 4, no. 1, p. 9-112.

JUNK, WJ. 1984. Ecology, fisheries and fich culture in Amazonia. In: SIOLI, H. (ed.). The Amazon, Limnology and landscape ecology of a mighty tropical fiver and its basin. Dordrecht: Dr. W. Junk. p. 443-476.

JUNK, WJ. 1993. Wetlands of Tropical South America. In WHIGHAM, D., HEJNÝ, S. and DYKYJOVÁ, D. (Eds.). Wetlands of the World I: inventory, ecology and management. Dordrecht: Dr. W. Junk Publ. p. 679-739.

JUNK, WJ. 2000. Neotropical Floodplains: a ContinentalWide View. In JUNK, WJ., OHLY, JJ., PPIEDADE, MTF. and SOARES, MGM. (Org.). The central Amazon Floodplain: actual use and options for a sustainable management. Leiden: Backhuys Publishers. p. 75-94.

JUNK, WJ. and FURCH, K. 1991. Nutrient dynamics in Amazonian floodplains: decomposition of herbaceous plants in aquatic and terrestrial environments. Verhandlungen des Internationalen Verein Limnologie, no. 24, p. 2080-2084.

JUNK, WJ. and PIEDADE, MTF. 1993a. Herbaceous plants of the Amazon floodplains near Manaus: species diversity and adaptations to the flood pulse. Amazoniana, vol. 12, no. 3/4, p. 467-484.

JUNK, WJ. and PIEDADE, MTF. 1993b. Species diversity and distribution of herbaceous plants in the floodplain of the middle Amazon. Verhandlungen des Internationalen Verein Limnologie, no. 25, p. 1862-1865.
JUNK, WJ. and PIEDADE, MTF. 1993c. Biomass and primary production of herbaceous plants communities in the Amazon floodplain. Hydrobiologia, vol. 263, p. 155-162.

JUNK, WJ. and PIEDADE, MTF. 1997. Plant life in the floodplain with special reference to herbaceous plants. In JUNK, WJ. (Ed.). The Central Amazon floodplain: ecological studies. Berlin: Springer. p. 147-185.

JUNK, WJ. and ROBERTSON, BA. 1997. Aquatic invertebrates. In JUNK, WJ. (Ed.). The Central Amazon floodplain: ecological studies. Berlin: Springer. p. 279-298.

JUNK, WJ. and SILVA, VMF. 1997. Mammals, reptiles and amphibians. In JUNK, WJ. (Ed.). The Central Amazon Floodplain: ecological studies. Berlin: Springer. p. 409-416.

JUNK, WJ., BAYLEY, PB. and SPARKS, RE. 1989. The floodpulse concept in the river-floodplain systems. Canadian Special Publication in Fisheries and Aquatic Sciences, no. 106, p. 110-127.

LOPES, A. 2007. Respostas de Herbáceas Aquáticas Amazônicas ao Petróleo Cru de Urucu (Coari-AM). Manaus, Amazonas: Instituto Nacional de Pesquisas da Amazônia/Universidade Federal do Amazonas. Master thesis in Ecology.

LOPES, A. and PIEDADE, MTF. 2009. Estabelecimento de Echynochloa polystachya (H.B.K.) Hitchcock (Poaceae) em solo de várzea contaminado com petróleo de Urucu. Acta Amazonica, vol. 39, no. 3, p. 583-590.

LOPES, A., D’ANGELO SA., JUNK, WJ., PIEDADE, MTF., MAURENZA, D., WITTMANN, FK., SCHÖNGART, J., MARINHO, TAS., FONSECAJUNIOR, SF. and ROSA, SA. 2008. Composição de Herbáceas na Planície de Inundação do Rio Jufari (igapó)- Amazonas - Brasil. In Conferência Cientifica Internacional do LBA, Geoma e PPbio.

LOPES, A., ROSA-OSMAN, SM. and PIEDADE, MTF. 2009. Effects of crude oil on survival, morphology, and anatomy of two aquatic macrophytes from the Amazon floodplains. Hydrobiology, vol. 636, no. 1, p. 295-305.

LYTLE, DA. and POFF, L. 2004. Adaptation to natural flow regimes. Tree, vol.19, no. 2, p. 94-100.

MELACK, JM. and HESS, LL. in press. Remote sensing of the distribution and extent of wetlands in the Amazon basin. In JUNK, WJ., PIEDADE, MTF., WITTMANN, F., SCHÖNGART, J. and PAROLIN, P. (Eds.) Amazonian Floodplain Forests: ecophysiology, ecology, biodiversity and sustainable management. New York: Springer. Ecological Studies Series.

MERCK, AMT. 1994. Aspectos taxonômicos, morfológicos $e$ autoecológicos de Pomacea lineata (PHILIPPI, 1851) e Pomacea papyracea (SPIX, 1827) Mollusca, Prosobranchia, nas áreas alagáveis nos rios Amazonas e 
Negro, AM. Universidade de São Carlos, Sáo Carlos. [Doctor Thesis].

NODA, H., JUNK, WJ. and PAHLEN, AVD. 1978. Emprego de macrófitas aquáticas (Matupá) como fonte de matéria orgânica na cultura de feijão-deasa (Psophocarpus tetragonolobus) em Manaus. Acta Amazonica, vol. 8, no. 1, p. 107-109.

NUNES, AL. 1989. Estudo sobre o ciclo de vida e fenologia de Stenacris fissicauda fissicauda (BRUNER, 1908) (Orthoptera - Acrididae) em um lago de várzea da Amazônia Central, Brasil. Manaus: INPA/FUA. [Master Thesis].

OHLY, J. and HUND, M. 1996. Pasture farming on the floodplains of Central Amazonia. Animal Research and Development, no. 43/44, p. 53-79.

OLIVEIRA, GC. 1992. Padrōes de variação fenotípica e ecologia de Oryza (Poaceae) selvagens da Amazônia. Piracicaba: Universidade de São Paulo. [Master Thesis].

ORDINEZ-COLLART, O. 1988. Ecologie de la crevette d'Amazonie, Macrobrachium amazonicum. In Commission des Communautés Euroéennes - CEE. Condicions ecologiques et economiques de la producion dune ile de Várzea: l'ile du Careiro. Rapport terminal. Orstom: INPA. p. 52-71.

PEREIRA FILHO, M., STORTI FILHO, A. and GRAEF, EW. 1987. Preparo e utilização de ingredientes produzidos em Manaus, no arraçoamento do matrinxã, Brycon sp. II. Teste experimental. In 5 Congresso Brasileiro de Engenharia de Pesca, Fortaleza. p. 187-199.

PIEDADE, MTF. and JUNK, WJ. 2000. Natural herbaceous plant communities in the Amazon floodplains and their use. In JUNK, WJ., OHLY, J., PIEDADE, MTF. and SOARES, MGM. (Eds.). The Central Amazon Floodplain: actual use and options for a sustainable management. [S.1.]: Backhuys Publishers b.v. p. 269-290.

PIEDADE, MTF., JUNK, WJ. and LONG, SP. 1991. The productivity of the C4 grass Echinochloa polystachya on the Amazon floodplain. Ecology, vol. 72, p. 1456-1463.

PIEDADE, MTF., LONG, SP. and JUNK, WJ. 1994. Leaf and canopy $\mathrm{CO}_{2}$ uptake of a stand of Echinochloa polystachya on the Central Amazon floodplain. Oecologia, vol. 97, p. 159-174.

PIEDADE, MTF., WORBES, M. and JUNK, WJ. 2001. Geo-ecological controls on elemental fluxes in communities of higher plants in Amazonian floodplains. In McCLAIN, ME., VICTORIA, RL. and RICHEY, JE. (Ed.). The Biogeochemistry of the Amazon Basin. New York: Oxford University Press. p. 209-234.

POTT, A. and POTT, VJ. 1996. Flora do Pantanal Listagem atual de Fanerógamas. In Anais II Simpósio sobre Recursos Naturais e Sócio-econômicos do Pantanal.
Manejo e Conservação. Corumbá: Embrapa Pantanal. p. 297-325.

POTT, VJ. and POTT, A. 2000. Plantas Aquáticas do Pantanal. Brasília: EMBRAPA. 404 p.

PRANCE, GT. 1978. The origin and evolution of the Amazon flora. Interciência, vol. 3, p. 207-230.

RUBIM, MAL. 1995. Ciclo de vida, biomassa e composição quimica de duas espécies de arroz silvestre da Amazônia Central. Manaus: INPA/FUA. [Master Thesis].

SAINT-PAUL, U., WENDER, U. and TEIXEIRA, AS. 1981. Use of water hyacinth in feeding trials with Matrinchã (Brycon sp.). Journal of Aquatic Plant Management, vol. 19, p. 18-22.

SCHLEGEL, A. 1998. Einfluss des Bodenwassergehaltes, der Düngung mit Stickstoff und des Mulchens auf die stomatäre Leitfähigkeit, das Pflanzenwachstum und die Produktion von Biomasse des C4-Grases Echinochloa polystachya im Überschwemmungsgebiet des Amazonas. Manaus, Brazil: Staatsexamensarbeit, Univ. Freiburg, Max-Planck Institut für Limnologie, AG-Tropenkologie, Plön, INPA.

SCULTHORPE, CD. 1985. The biology of aquatic vascular plants. Königstein: Koeltz Scientific Books.

SIOLI, H. 1951. Alguns resultados e problemas da limnologia amazônica: Instituto Agronômico do Norte. Boletim Técnico, no. 24.

SOARES, MGM., ALMEIDA, RG. and JUNK, WJ. 1986. The trophic status of the fish fauna in Lago Camaleão, a macrophyte dominated floodplain lake in the middle Amazon. Amazoniana, vol. 9, no. 4, p. 511-526.

THOMAZ, SM. and BINI, LM. 2003. Ecologia e manejo de macrófitas aquáticas. Maringá: Universidade Estadual de Maringá.

THOMAZ, SM., PAGIORO, TA., BINI, LM., ROBERTO, MC. and ROCHA, RRA. 2004. Limnology of the Upper Paraná floodplain habitats: patters of spatio-temporal variations and influence of the water levels. In AGOSTINHO, AA., RODRIGUES, L., GOMES, LG., THOMAZ, SM. and MIRANDA, LE. (Eds.). Structure and functioning of the Parana river and its floodplain. Maringá: EDUEM. p. 39-42.

VIEIRA, MF. 1989. Bionomia e biologia de Paulinia acuminata (DE GEER) (Orthoptera: Pauliniidae) em um lago de várzea da Amazônia Central. Manaus: INPA/FUA. [Master Thesis].

VIEIRA, MF. and ADIS, J. 1992. Abundance and biomass of Paulinia acuminata (DE GEER, 1773) (Orthoptera: Pauliniidae) in a várzea lake of Central Amazonia. Amazoniana, vol. 7, no. 2, p. 337-352.

WEAVER, JE. and CLEMENTS, FE. 1938. Plant ecology. 2nd ed. New York: McGraw-Hill.

WITTMANN, F., ANHUF, D. and JUNK, WJ. 2002. Tree species distribution and community structure of 
central Amazonian várzea forests by remote-sensing techniques. Journal of Tropical Ecology, vol. 18, p. 805-820.

WITTMANN, F., SCHÖNGART, J., MONTERO, JC., MOTZER, T., JUNK, WJ., PIEDADE, MTF., QUEIROZ, HL. and WORBES, M. 2006. Tree species composition and diversity gradients in white-water forest across the Amazon basis. Journal of Biogeography, vol. 33, p.1334-1347.

WORBES, M. 1997. The forest ecosystem of the floodplains. In JUNK, WJ. (Ed.). The Central Amazon
Floodplain. Springer, Berlin: Ecological Studies. p. 223-265.

WORBES, M., KLINGE, H., REVILLA, JD. and MARTIUS, C. 1992. On the dynamics, floristic subdivision and geographical distribution of Várzea forests in Central Amazonia. Journal of Vegetation Sciences, vol. 3, p. 553-564.

Received: 13 June 2010 Accepted: 26 August 2010 